UDC 004.04

JEL Classification: C45, M15, O32

MAKOIEDOVA Valentyna,

Postgraduate student of the Department of Software Engineering and Cybersecurity

Kyiv National University of Trade and Economics

19, Kyoto str., Kyiv, 02156, Ukraine

E-mail:v.makoedova@knute.edu.ua

ORCID: 0000-0001-7518-894X

\title{
INEORMATION TECHNOLOGIES IN DECISION SUPPORT SYSTEMS
}

The article considers classification of decision support systems by the way of interaction with the user, by the method of support, by the level of data processed by the system. Types of DSS architecture are presented. Intelligent DSS are analyzed. The main areas of research in the field of artificial intelligence are identified. The advantages and disadvantages of using neural networks are revealed. Cloud technologies are highlighted as an important trend in the development of modern DSS. The properties of Big Data technology are determined.

Keywords: decision support systems, information technology, intelligent decision support systems, artificial intelligence, neural networks, cloud technologies, Big Data, Big Data Analytics.

Макоедова В. Информационные технологии в системах поддержкки принятия решений. Рассмотрена классификация систем поддержки принятия решений (СППР) по способу взаимодействия с пользователем по методу поддержки, уровню данных, обрабатываемых системой. Представлены типы архитектуры СППР. Проанализированы интеллектуальные СППР. Выявлены преимущества и недостатки использования нейронных сетей. Выделены облачные технологии как важная тенденция развития современных СППР. Определены особенности Big Data.

Ключевые слова: система поддержки принятия решений, информационные технологии, интеллектуальные системы поддержки принятия решений, искусственный интеллект, нейронные сети, облачные технологии, Big Data, Big Data Analytics.

Background. Information technologies are developing rapidly nowadays. Under such conditions, approaches to the development of decision support systems begin to change. There are growing opportunities to improve the functionality of systems, change the algorithms of their work and speed up the decision-making process as a whole. Also, the amount of information that needs to be analyzed is constantly growing. Under such circumstances, the requirements for the functionality of decision support systems are essential. Considering the diversity of IT, it is important to identify those technologies that will have the most significant impact on the further development of decision support systems in the near future.

(C) Makoiedova V., 2020 
Analysis of recent researches and publications. A number of scientific works of domestic and foreign scientists have been devoted to the study of the development of decision support systems. In particular, the issue of application of information technologies in decision making was studied by M. Sayensus and G. Karnaukhova [1] in their scientific work. O. Veres [2], M. Demydenko [3] S. Churubrova [4] investigated the state and development of decision support systems.

Additionally, a number of studies have been devoted to the application particular technologies for decision support system. Thus, H. Ivanchenko and O. Stetska [5], O. Veres [6] studied modern perspectives of cloud decision support system. Scientific work of S. Subbotin [7] was dedicated to investigation of artificial intelligence systems usage in decision support process.

The aim of the article is to identify the key trends of development of information technology in decision support systems at the present stage.

Materials and methods. The theoretical and methodological basis for writing the article were the works of domestic and foreign scientists on the functioning of decision support systems, the impact of information technology on their development, and current trends of information technology development in decision-making sphere. The study was conducted using the methods of theoretical generalization, comparative analysis and synthesis, which allowed clarifying the specific features of decision support systems, identifying the key trends in developing of information technology in decision support systems.

Results. An important area of economics' decision-making science is decision-making in conditions of uncertainty. Terms of uncertainty corresponds to the situation where the results of the decisions made are unknown. Uncertainty is divided into stochastic, behavioral, natural and a priori. The task of substantiating decisions in conditions of uncertainty of all types, except a priori, is reduced to the narrowing of the original set of alternatives on the basis of information possessed by the decision maker. The quality of recommendations for decision-making in conditions of stochastic uncertainty increases when taking into account such characteristics of the decision-maker as the attitude to their gains and losses and the attitude to risk. Substantiation of decisions in the conditions of a priori uncertainty is carried through algorithms of adaptive management [8]. It is necessary to take into account the ambiguity and diversity of factors and parameters at the time of decision-making, high dynamism and nonlinearity social and economic processes, the role of the individual in the process of development, justification and decision-making [9].

The range of software that implements objective mathematical methods of decision support in conditions of uncertainty is quite wide: from individual information processing programs and solving computational problems to automated decision support systems [1]. Decision support system (DSS) is an automated computer system that aims to help people who make decisions in difficult conditions for a complete and objective analysis of the subject activity. DSS arose as a result of the merger of management information 
systems and database management systems [8]. Nowadays, DSS is considered as a promising area of computer technology and a tool to improve efficiency in various branches [10].

DSS can be classified as follows:

- by the way of interaction with the user: passive (help to make decisions, but cannot make specific proposals), active (directly involved in developing the right solution), cooperative (allow you to modify, supplement or improve the solutions proposed by the system, by adjusting them);

- by the method of support: Model-Driven DSS (uses access to statistical, financial or other models in their work), Communication-Driven DSS (supports the work of several users united by a common cause), DataDriven DSS (has an access to the time series of the organization, use both internal and external data), Document-Driven DSS (works with unstructured information in various electronic formats), Knowledge-Driven DSS (provides specialized solutions to problems based on facts) [1];

- by the level of data processed by the system: operational (immediately responds to changes in the current situation of management of financial and economic processes of the company), strategic (is used to analyze large amounts of heterogeneous information obtained from different sources) [2].

It should be noted, that some systems that allow to perform complex data analysis are hybrid DSS which provide modeling, retrieval and data processing [8]. Most of the DSS systems currently in use are hybrid systems. Hybrid DSS systems are usually developed for specific requirements and conditions. These systems contain the positive properties of different systems and minimize the negative aspects of the combined systems. There are two main approaches to DSS integration: nesting and synergy. Nesting methods involve the transfer of the properties of the nested system to the system that received this subsystem. In a synergetic approach to the integration of different systems, there is no nesting, no dominant technology, no nested systems and methods. All methods are integrated into a single tool that allows them to be used [3].

There are four of the most popular types of DSS architecture at present:

- Functional DSSs are the simplest, they are compact and efficient and are used in companies that do not set comprehensive goals. They analyze the data contained in operating systems.

- DSS using independent data showcases. Each specific data showcase is designed for a specific group of users and is created to solve specific tasks. They are used in organizations where there are several departments. The implementation of such systems is quite simple.

- DSS based on a two-tier data warehouse is recommended for use in large companies whose data are collected in a single system. Definitions and methods of information processing in these systems are standardized.

- DSS based on a three-tier data warehouse provides access to both specific structured data and single aggregated information.

Modern DSS developments are mainly implemented by either crisis management models related to the withdrawal of a complex system from the 
crisis in the uncertainty of the initial circumstances, or methods of intellecttual analysis for strategic planning procedures [1]. Different methods are used to analyze and develop proposals in DSS: information retrieval; data mining; search of knowledge in databases; reasoning based on precedents; simulation modeling; evolutionary calculations and genetic algorithms; situational analysis, etc. Some of these methods have been developed as part of artificial intelligence. If the work of DSS is based on the methods of artificial intelligence, then is talked about intelligent DSS (IDSS) [8].

IDSS is a result of combining DSS and artificial intelligent (AI). Its basic design is to combine the knowledge reasoning techniques of $\mathrm{AI}$ and the basic function models of DSS. IDSS is needed and is economically feasible for generic problems that require repetitive decisions. IDSSs are interactive computer-based systems that use data, expert knowledge and models for supporting data mining in organizations to solve semi structured problems by incorporating artificial intelligence technique [11].

Information Technology (IT) is now a force and driver of modern technological development and globalization, and makes the management of information more efficient and effective. IT is generally accepted as a key enabler of economic and technological growth. Information Technology has unlimited potential to improve business operations, education, technology and economic growth [12]. The development of information technology has a significant impact on the future of DSS and IDSS in modern conditions. We would like to consider in more detail the technologies, the further development of which is crucial for decision support systems.

Artificial intelligence is one of the biggest areas of focus for future technology development. To make execution of tasks faster, simpler and cheaper, organizations are continuously exploring ways of enabling machines to do more and more of what humans currently do. This has the impact of reducing operational costs in the long run, while at the same time eliminating the need for some jobs held by humans [12].

The main areas of research in the field of artificial intelligence:

- presentation of knowledge and work with them is the creation of specialized models and languages for representation of knowledge in the computer, and also software and hardware for their transformation;

- planning appropriate behavior is the research to create methods for setting goals and solving problems of planning the actions of an agent operating in a complex external environment;

- human communication with a computer is the task of creating language tools that allow you to effectively interact with a computer to a nonprogramming user;

- pattern recognition and learning is a research on the perception of visual, auditory and other types of information, methods of its processing, the formation of appropriate reactions to environmental influences and ways to adapt artificial systems to the environment through learning [7]. 
The next technology is neural networks. They develop trends or patterns of user behavior over time. When activity is outside the normal pattern the neural network raises an alarm. These systems are growing in use in many different fields and will provide greater support to human beings in rapid decision making [12].

In the last decade, neural networks have been actively used to solve complex problems in the humanities, sociology, economics, etc. The results of the use of neural networks in various fields of activity allow us to identify the following advantages over traditional mathematical methods:

- parallelism of information processing is globality of connections between neurons (before training connections between neurons are arbitrary, but training on examples forms structure of a network under a concrete task);

- the presence of a single and effective principle of learning neural networks is minimization of empirical error by its method of back propagation on the network (externally sets only the purpose of training, i.e. the method of determining the error at the network outputs; then the network gradually modifies its configuration, minimizing the error, better coping with the task assigned to it);

- the ability to learn from examples in cases where the patterns of the situation are unknown with an indefinite relationship between input and output data, as well as in cases of incomplete, inaccurate and internally contradictory input information;

- high speed of learning and obtaining a solution;

- reliability of operation (redundancy of connections leads to the fact that the value of each weight does not play a decisive role; the exclusion of a limited number of neurons or the breakdown of individual connections does not critically affect the quality of the network);

- the ability to find the optimal parameters for a particular tool and build an adequate model for a given set of input data, neural network models are able to adapt and change according to the situation, which is especially important in an unstable economic situation;

- the ability to solve informal problems (neural network is able to independently produce very complex algorithms for data processing, which in most cases cannot be formalized by experts in the subject area on their own);

- relative cheapness of neural network developments;

- reprogrammability.

The disadvantages of neural networks include their hidden nature of functioning [13].

Another important trend in the development of modern DSS is the shift of their functional into cloud services and the development of cloud computing technologies. The decision support system in the cloud allows you to produce real-time data from data center servers or external sources, offer solutions to problems based on the rules stored in the knowledge base, providing results for visualization in a user-friendly language form [5]. 
Cloud computing is a network of resources a company can access, and this method of using a digital drive increases the efficiency of organizations. Instead of local storage on computer hard drives, companies will be freeing their space and conserving funds. Cloud storage and sharing is a popular trend many companies have adopted and even implemented for employee interaction. A company-wide network will help businesses save on information technology infrastructure. Cloud services will also extend internal functions to gain revenue. Organizations that offer cloud services will market these for external products and continue their momentum. Organizations will transfer their stored files across multiple sources using virtualization. Companies are already using this level of virtualization, but it will be embraced in the next year. Less installation across company computers is another positive result of cloud computing because the Internet allows direct access to shared technology and information. The freedom of new products and services makes cloud computing a growing trend [14].

According to the unanimous forecasts of the world's leading consulting companies, the rapid improvement and spread of cloud technologies is one of the key trends now. It will significantly affect the global development not only the IT industry but also business, finance, government, medicine, education and many other areas of human life in the next 5-8 years. Technology that allows organizations and other entities to avoid significant costs of their own IT infrastructure in favor of obtaining all necessary IT resources online is considered promising taking into account the advanced development of information and communication technologies (ICT) and the next downturn in the global economy [6].

There is a significant increase in the amount of information that needs to be processed in parallel with the development of information technology. Accordingly, the further development of DSS is directly related to Big Data and Big Data Analytics technology.

The concept of "Big Data" involves working with information of huge volume and variety, which is very often updated and contained in various sources in order to increase efficiency, create new products and increase competitiveness. Big Data in information technology is a set of methods and tools for processing structured and unstructured different types of largescale dynamic data for analysis and use to support decision-making. Big Data as a technology has the following properties:

- it is possible to process very large amounts of data;

- storage media are inexpensive;

- data are guided by the "Roman Census" method;

- data controlled by Big Data is unstructured [2].

Today, decision-makers are confronted with a large amount of diverse data, which comes with tremendous speed and with potentially high variability. The growing volumes of raw data, along with the need for real-time analysis, require the creation and implementation of tools that can effecttively solve this problem. New tools for analysis are needed because the data are not just more than before, but more of their external and internal 
sources, now they are more complex and diverse (structured, unstructured and quasi-structured), use different indexing schemes (relational, multidimensional, noSQL). It is no longer possible to deal with data in the old ways as Big Data Analytics extends to large and complex arrays, providing decisionmakers with information about various processes in an acceptable form [4].

Big data is a trend that allows businesses to analyze extensive sets of information to achieve variety in increasing volumes and growth of velocity. Big data has a high return on investment that boosts the productivity of marketing campaigns, due to its ability to enable high-functioning processsing. Data mining is a way companies can predict growth opportunities and achieve future success. Examination of data to understand markets and strategies is becoming more manageable with advances in data analytic programs [14].

Most often, SN-architecture (Shared Nothing Architecture) is used as the basic principle of big data processing. $\mathrm{SN}$-architecture provides massiveparallel processing that scales without degradation to hundreds and thousands of processing nodes [2].

If development of informational technologies proceeds in accordance with theirs current trends, then it would have both technological and economic impact on further evolution of DSS. Brief summarization of IT whose development would have significant impact on further DSS upgrowth is presented in the table.

Table

Potential impact of IT usage on further DSS development

\begin{tabular}{|c|c|}
\hline Information technology & Possible impact on the further development of DSS \\
\hline $\begin{array}{l}\text { Artificial } \\
\text { intelligence }\end{array}$ & $\begin{array}{l}\text { Creation of dynamic systems capable of self-learning based on given } \\
\text { parameters or samples. } \\
\text { Adaptation of DSS operation to complex external environment conditions. } \\
\text { Acceleration of the decision-making process under multifactorial terms. } \\
\text { Reduction of labor costs for the decision-making process }\end{array}$ \\
\hline $\begin{array}{l}\text { Neural } \\
\text { networks }\end{array}$ & $\begin{array}{l}\text { They can be used for decision-making in various fields of activity. } \\
\text { DSS developed based on neural networks would be especially effective } \\
\text { in rapid decision making. } \\
\text { Due to neural networks, DSS will be able to suggest a decision even } \\
\text { is cases of incompleteness, inaccuracy or internal contradictory of input } \\
\text { information. } \\
\text { DSS will be able to solve non-formalized problems }\end{array}$ \\
\hline $\begin{array}{l}\text { Cloud computing } \\
\text { technologies }\end{array}$ & $\begin{array}{l}\text { Ability to offer solutions to problems based on the rules stored } \\
\text { in the knowledge base. } \\
\text { Production of data from data center servers or external sources } \\
\text { and decision-making in real-time. } \\
\text { DSS based on cloud computing technologies would increase } \\
\text { general efficiency of organizations. } \\
\text { As there is no specific system requirements for using of cloud-based } \\
\text { DSS, companies have the ability to reduce hardware costs }\end{array}$ \\
\hline $\begin{array}{c}\text { Big Data Analytics } \\
\text { technology }\end{array}$ & $\begin{array}{l}\text { Ability to quickly process large data sets in real-time. } \\
\text { Ability to proceed structured, unstructured and quasi-structured data. } \\
\text { Reduction of costs on storage media }\end{array}$ \\
\hline
\end{tabular}

Source: compiled by the author according to the materials $[2 ; 4-5 ; 7 ; 12-14]$.

Summarizing the above, it should be noted that the use of these technologies is not mutually exclusive. On the contrary, a symbiosis of several technologies will expand the functional potential of future DSS development. 
Conclusion. Decision support systems have specific features. Information technology has a significant impact on the development of DSS. Priority trends in the development of information technology in DSS are the use of artificial intelligence, neural networks, cloud technologies, Big Data.

The result of the combination of DSS and artificial intelligence is intelligent decision support systems. The use of neural networks in the decisionmaking process is growing, despite the hidden nature of their functioning. Cloud technologies are rapidly improving now. They are spreading noticeably, affecting the global development of many areas of life. The development of DSS is associated with Big Data technologies for processing structured and unstructured large amounts of dynamic data. Big Data Analytics provides decision makers with acceptable information about various processes.

\section{REFERENCES}

1. Sayensus, M. A., \& Karnaukhova, G. S. (2017). Pryynyattya upravlins'kykh rishen': vykorystannya informatsiynykh tekhnolohiy [Management decision making: using information technology]. Scientific Bulletin of Kherson State University, 23, 173-177. Series "Economic Sciences" [in Ukrainian].

2. Veres, O. M. (2015). Aspekty proyavu nevyznachenosti v protsesakh rozroblennya system pidtrymky pryynyattya rishen' [Aspects of uncertainty in the development of decision support systems]. Bulletin of Lviv Polytechnic National University, "Information Systems and Networks", 829, 58-75 [in Ukrainian].

3. Demydenko, M. A. (2016). Systemy pidtrymky pryynyattya rishen' [Decision support systems]. Dnipro: Dnipro University of Technology [in Ukrainian].

4. Churubrova, S. M. (2015). Suchasni tekhnolohichni aspekty system pidtrymky pryynyattya rishen' [Modern technological aspects of decision support systems]. Problems in programming, 3, 86-92 [in Ukrainian].

5. Ivanchenko, H. F., \& Stetska, O. P. (2016). Modern perspectives of cloud DSS in the banking sector. Market infrastructure, 2, 361-364 [in Ukrainian].

6. Veres, O. M. (2016). Vybir khmarnoyi tekhnolohiyi v proekti SPPR z keruvannya velykymy danymy [The choice of cloud technology in the DSS project for big data management]. Bulletin of Lviv Polytechnic National University, "Information Systems and Networks", 854, 11-20 [in Ukrainian].

7. Subbotin, S. O. (2008). Podannya ta obrobka znan' u systemakh shtuchnoho intelektu ta pidtrymky pryynyattya rishen' [Presentation and processing of knowledge in artificial intelligence systems and decision support]. Zaporizhia: Zaporizhzhia Polytechnic National University [in Ukrainian].

8. Bessmertnaya, D. V. (2017). Informatsiyno-analitychni systemy i tekhnolohiyi pryynyattya rishen' v ekonomitsi [Information-analytical systems and decisionmaking technologies in economics]. Suchasni informatsiyni tekhnolohiyi ta systemy v upravlinni: zb. materialiv I Vseukr. nauk.-prakt. konf. molodykh vchenykh, aspirantiv i studentiv [Modern information technologies and systems in management: coll. materials and All-Ukrainian. scientific-practical conf. young scientists, graduate students and students]. Kyiv: KNEU, 20-23 [in Ukrainian].

9. Vitlins'kyy, V. V. (2012). Shtuchnyy intelekt u systemi pryynyattya upravlins'kykh rishen' [Artificial intelligence in the system of managerial decision making]. Neuro-Fuzzy Modeling Techniques in Economics, 1, 97-118 [in Ukrainian]. 
10. Vasylykiv, I. (2011). Tendentsiyi stanovlennya ta rozvytku informatsiynykh system i tekhnolohiy [Trends in evolutionand development of information systems and technology]. Youth \& market, 1, 141-144 [in Ukrainian].

11. Rajan Vohra \& Nripendra Narayan Das (2011). Intelligent decision support systems for admission management in higher education institutes. International Journal of Artificial Intelligence \& Applications (IJAIA). Vol. 2, 4, 63-70 [in English].

12. Kabanda, G. (2019). Trends in information technology management. Retrieved from https://www.researchgate.net/publication/334672466_Trends_in_Information Technology_Management [in English].

13. Holoven', O. V. (2012). Otsinka vplyvu faktoriv zovnishn'oho seredovyshcha na operatsiynu diyal'nist' pidpryyemstva na pidgrunti neyronnykh merezh [Assessment of the impact of environmental factors on the operating activities of the enterprise on the basis of neural networks]. Neuro-Fuzzy Modeling Techniques in Economics, 1, 119-141 [in Ukrainian].

14. Trends in Information Technology for 2019. Retrieved from https://www.vistacollege.edu/blog/careers/it/trends-in-information-technologyfor-2019 [in English].

The article submitted to editor's office on 06.07.2020. рімень.

Макоєдова В. Інформаційні технологї у системах підтримки прийняття

Постановка проблеми. У сучасних умовах спостерігається посилення вимог до функиіональності систем підтримки прийняття рішень. Враховуючи різноманітність IT, важливо визначити ті технології, які найближчим часом найбільше впливатимуть на подальший розвиток систем підтримки прийняття рішень (СППР).

Аналіз останніх досліджень і публікацій показав, що застосування інформаційних технологій у прийнятті рішень, стан та розвиток СППР активно вивчаються українськими та закордонними дослідниками.

Метою статті є виявлення ключових тенденцій розвитку інформаційних технологій у системах підтримки прийняття рішень.

Матеріали та методи. Інформаційною базою для написання статті стали праці вітчизняних та зарубіжних учених щзодо функціонування СППР, впливу інформачійних технологій на їх розвиток. Дослідження проводилось з використанням методів теоретичного узагальнення, порівняння, аналізу та синтезу.

Результати дослідження. Представлено класифікацію систем підтримки прийняття рішень за способом взаємодії з користувачем, методом підтримки, рівнем даних, що обробляються системою. Визначено типи архітектури СППР. Розглянуто технології, подальший розвиток яких має вирішальне значення для СППР.

Інтелектуальні системи підтримки прийняття рімень - результат поєднання СППР та штучного інтелекту. Незважаючи на прихований характер функціонування, зростає використання нейронних мереж у процесі прийняття рішень. Швидке вдосконалення та розповсюдження хмарних технологій - одна з ключових тенденцій, яка суттєво вплине на глобальний розвиток багатьох сфер життя. Для обробки структурованих та неструктурованих великих обсягів динамічних даних подальший розвиток СППР безпосередньо пов'язаний з технологіями Big Data ma Big Data Analytics. Haйчастіше $S N$-архітектура використовується як основний принщип обробки великих даних.

Висновки. Системам підтримки прийняття рімень притаманні специфічні особливості. Інформаційні технології мають вагомий вплив на розвиток СППР. Пріоритетними тенденціями розвитку інформаційних технологій у СППР є використання штучного інтелекту, нейронних мереж, хмарних технологій, Big Data.

Ключові слова: система підтримки прийняття рішень, інформаційні технології, інтелектуальні системи підтримки прийняття рішень, штучний інтелект, нейронні мережі, хмарні технології, Big Data, Big Data Analytics. 